Terry D. Clark*

Kreitono universitetas

\title{
JAV užsienio politika po 2006 m. rinkimų i Kongresą: neokonservatizmas ir jo oponentai
}

\begin{abstract}
$2001 \mathrm{~m}$. rugsejjo 11-osios dienos teroristinės atakos paskatino Busho administraciją JAV užsienio politiką pakreipti grupės intelektualu ir politiku, žinomu kaip neokonservatoriai, propaguota linkme. Dabar, praejjus šešeriems metams, tapo aišku, kad, nors JAV užsienio politikos elitas atmeta pagrindines neokonservatoriu nuostatas, o tuo pat metu nesutaria dẻl bent kiek aiškesnės alternatyvos. Todẻl panašu, kad artimiausiu metu ir vèliau JAV su kiekviena naujai iškylančia tarptautine krize teks „dorotis“ atskirai, nesiejant šios veiklos su bendra šalies užsienio politikos strategija. Dèl šios „neholistinės“ prieigos Jungtinès Valstijos bus priverstos tik reaguoti i pasaulio politikos problemas ir užleisti iniciatyvą tiems, kas aiškiau sugeba apsibrèžti savo nacionalinius tikslus ir interesus. Tarp jų akivaizdžiausiai išsiskirs Kinija, Iranas ir vẻl agresyvëjanti Rusija.
\end{abstract}

\section{Ivadas}

Po šešerių metų nuo George'o W. Busho prezidentavimo pradžios įvykę Kongreso rinkimai atrodo paveikė nekonservatyvią užsienio politiką, kuri savo laiku buvo atsakas į rugsëjo 11-osios įvykius. $2006 \mathrm{~m}$. rinkimai buvo nesėkmingi respublikonams, nes rinkimuose Kongresu rūmuose dauguma atiteko Demokratu partijai, kuri, nors ir nežinojo kaip tai geriausia padaryti, vis tiek buvo pasiryžusi keisti JAV užsienio politiką. Respublikonu pralaimèjimą lẻmė visuomenės nusiteikimas, kad Busho administracija ịtraukẻ šalị i karą Irake, kuris kainuoja per daug ištekliu ir žmoniu gyvybių. Gana keista, tačiau prezidento reitingui, kuris ilgą laiką priklausẻ nuo karo eigos, labiau pakenkè uraganas „Katrina“ nei nuolatinis nepasitenkinimas karu. Nors visuomenè buvo gerai informuota apie karą, vis dèlto prezidentas dar laimejjo $2004 \mathrm{~m}$. rinkimus teigdamas, kad jis geriausiai žino, kaip kovoti su terorizmu. Tačiau vangi administracijos reakcija ị uragano „Katrina“ padarinius bylojo apie kompetencijos stoką ir pakirto visuomenės pasitikëjimą prezidentu. Tą netrukus patvirtino Kongreso rinkimų rezultatai.

\footnotetext{
* Dr. Terry D. Clark - Kreitono universiteto (Nebraska, JAV) politikos mokslų profesorius, tarptautiniu santykiu magistro programos direktorius. Adresas: Creighton University, Omaha, NE 68178, e. paštas-tclark@ creighton.edu
} 
Taigi demokratams, taip ir neprisiẻmusiems aiškesnių įsipareigojimu, išskyrus miglotą pažadą imtis pokyčiu, atiteko didelè valdžia. Tačiau vẻliau, kaip netruko paaiškèti, demokratai buvo labiau vieningi vidaus, bet ne užsienio politikos, ar konkrečiai karo Irake klausimais. Vieni iš ju pasisakẻ už pajègu išvedimą iš Irako nedelsiant, antri ragino tai daryti laipsniškai, o treti manè netgi priešingai - rèmė Busho planą siųsti daugiau pajègų. Šie demokratų nesutarimai leido prezidentui įveikti Kongreso pasipriešinimą ir atsilaikyti prieš visuomenès nepritarimą ir 2007 vasarą padidinti karių skaičių Irake.

Vis dèlto, atrodo, kad prezidentui ir respublikonams teks keisti savo strategiją 2008 metų rinkimų metu. Jeigu tai nebus daroma, jie rizikuoja prarasti ne tik Baltuosius rūmus, bet ir patirti dar didesnius nuostolius kovoje dèl vietų Senate ir Atstovų Rūmuose. Tačiau bet kokie fundamentalūs pokyčiai užsienio politikos strategijoje tuo pačiu reikštu ir neokonservatyviujų idejjų atmetimą bei būtinybę pradèti projektuoti naują užsienio politiką. Bet, atrodo, kad kol kas jokia nauja užsienio politikos koncepcija nèra išsikristalizavusi. Jei iš tikruju būtų tokia, tai demokratai sugebėtų sutelkti savo partiją ir visuomenę ir jau dabar priverstų prezidentą Bushą sutikti su jų reikalavimais, kad šalis išvengtu įsitraukimo į dar didesnę operaciją 2007 metų vasarą Irake.

Straipsnio pradžioje aš pristatysiu neokonservatyviosios užsienio politikos paradigmos atsiradimo istoriją ir jos turinį. Po to apžvelgsiu nesėkmingas pastangas ją pakeisti kita paradigma. Aš tvirtinu, kad, nors neokonservatizmas ir buvo atmestas politiku, kol kas nèra jokios intelektualinės alternatyvos, kuri ji galètu pakeisti. Išvadose bus pateiktas šios situacijos poveikio JAV užsienio politikai vertinimas.

\section{JAV užsienio politika šaltojo karo metu}

Valstybės, siekiančios konkrečių užsienio politikos tikslų, niekaip negali išsiversti be platesnès užsienio politikos tikslų vizijos. Nors tokia vizija pati savaime neapsprendžia nacionalinių interesu, bet pastarieji vis tiek negali būti igyvendinti be užsienio politikos elitą vienijančios pasaulèžiūros, be ilgalaikio šalies įsipareigojimo tam tikrai veiksmų krypčiai, be visos tarptautinès sistemos užtikrinimo, kad valstybė elgsis būtent taip, o ne kitaip. Platesnè užsienio politikos vizija suteikia šį labai svarbų bet kurios šalies užsienio politikai elementą.

Šaltojo karo metu JAV nacionalinis interesas užtikrinti šalies saugumą buvo siekiamas skleidžiant laisvos rinkos ir demokratijos idejjas. İsipareigojimas laisva rinka grịstai demokratijai rẻmėsi Vakaruose vyraujančiu įsitikinimu, kad Antraji pasaulinį karą sukèlè ekonominių sunkumų kamuojamos autoritarinės valstybès, kurios labai troško plèsti savo politinę įtaką. Todèl geriausias būdas apsisaugoti nuo diktatūru - skatinti atviros, liberalios rinkos ekonomikos vystymąsi. Remdamasis šia prielaida, George'as F. Kennanas parašè savo izžymujị 
esé $\dot{e}^{1}$ teigdamas, kad Sovietų Sajunga, kaip ir visos kitos diktatūros, iš prigimties yra ekspansionistinè valstybé. Jos ekonominė sistema paremta visuomenès ekonomine prievarta ir išnaudojimu bei pažadu, kad šalis vèliau suklestès. Tačiau šio pažado nebuvo įmanoma iggyvendinti dèl to, kad šalyje neveikè laisva rinka. Valdantysis komunistinis elitas turëjo ieškoti išorinių priešu, kuriuos galètų kaltinti dèl to, kad sistema negali išpildyti teiktų ekonominių pažadų. Neužtenka įvardyti priešą, su juo reikia ir kovoti, reikia vykdyti ekspansiją. Kaip tik todèl Kennanas ir teigè, kad JAV šioje situacijoje tenka svarbiausias uždavinys - užsiimti sulaikymu (ang. Containment), t. y. sulaikyti Sovietų Sąjungą ir neleisti jai realizuoti savo noro plèsti politinę įtaką. Tuomet uždaryta savo viduje sovietų visuomenė galiausiai pavargs nuo režimo klaidu, ir politinė sistema subyrès iš vidaus.

Kennano idejja apie sovietu ,"sulaikymo“" politiką suvienijo JAV užsienio politikos elito atstovus šaltojo karo metu. Nepaisant didelių nuostoliu, kuriuos JAV patyrė Korejjos ir Vietnamo karuose, prezidentai ir svarbūs užsienio politikos veikëjai liko ištikimi šiai vizijai, kurios įtakaa ir intelektualus patrauklumas rèmèsi jos aiškumu ir paprastumu. Remiantis šia idejja buvo ne tik sukonstruota globali dvieju poliu tarptautinè sistema, bet ir į aukščiausių vertybiu lygmenị buvo pakylèti pagrindiniai JAV interesai - laisva rinka ir demokratija. Dèl šios priežasties Vidurio ir Rytų Europos visuomenès kaip nesusipratimą vertino JAV prezidento George'o Busho vyresniojo raginimą atsiskyrimo nuo SSRS siekiančiu respublikų parlamentams likti Sovietų Sajungoje. „Sulaikymo“ paradigma pasiteisino, igyvendinant JAV užsienio politiką, todèl, net nusilpus Sovietų Sajungai, jos nenorèta atsisakyti. JAV norèjo tęsti globalios sistemos valdymą „dvipoliu“ principu, pagal kurị Sovietų Sajunga neturëjo sugriūti, o tik būti žymiai susilpninta, kad laisva rinka ir demokratija dominuotu pasaulyje.

Tačiau taip neįvyko. Iš tikruju, net jei Sovietų Sajunga ir būtų sugebëjusi išlaikyti savo vientisumą, vis tiek jos įsipareigojimų komunistiniam blokui žlugimas drauge reiškè ir buvusios tarptautinès sistemos pabaigą. Naujai besiformuojančiai tarptautinei sistemai reikëjo ir naujos užsienio politikos sistemos. Tačiau tuo metu jos skubiai nepavyko suformuluoti. Tokia situacija buvo pastebima ir prezidento Busho vyresniojo prieš pat Sovietų Sajungos žlugimą pasirašytoje JAV Nacionalinio saugumo strategijoje. Jos trumpas pavadinimas - „Isipareigojimas" (ang. Engagement) - žymèjo tai, kad Jungtinès Valstijos ir toliau turètų prisidèti prie tarptautinès sistemos valdymo, tačiau tai nebuvo strategija, o tik susiklosčiusios situacijos apibūdinimas, skirtas užsienio politika beveik nesidominčiai JAV visuomenei. Didžiausia administracijos užsienio politikos problema buvo ta, kad nebuvo aiškios koncepcijos, ko turi siekti JAV tarptautinëje erdvëje, iširus Sovietų Sąungai. Todèl ir liko tik deklaruoti įsipareigojimą neapibrèžtos „naujos pasaulio tvarkos" kūrimui.

\footnotetext{
${ }^{1}$ X [George F. Kennan], „,Sources of Soviet Conduct“, Foreign Affairs, July 1947.
} 


\section{Globalizacijos era}

Artëjant Sovietų Sajungos žlugimui, JAV intelektualai plètojo dvi idëjas, kurios galëjo tapti intelektiniu naujos tarptautinės sistemos ir JAV užsienio politikos pagrindu. Jos buvo išdèstytos Francio Fukuyamos straipsnyje „Istorijos pabaiga“ ir Samuelio Huntingtono - „Civilizacijų susidūrimas“”. Fukuyamos idejjos buvo labiau optimistinès. Jis teigè, kad komunizmas buvo paskutinis didelis varžovas laisva rinka paremtai demokratijai, o jo žlugimas galiausiai reiškė, kad baigėsi didžiujų ideologijų kova ir pergale atiteko liberalizmui. Gal kokios valstybės atskalūnės (ang. rogue states) ir toliau nesusitaikys su šia nauja realybe, tačiau tarptautinè bendruomenè kaip visuma neturi kito pasirinkimo. Galbūt ir toliau pačios valstybės spręs savo šalies vidaus konfliktus, bet galingiausios pasaulio valstybės jau nebesivaržys dèl to, kaip turi būti organizuojama visuomenè, ir koks turi būti valdymas. Ir nebebus prasmès žūtbūt su kuo nors kovoti. O tai iki minimumo sumažina branduolinio arba visuotinio karo tikimybę. Dabar pasaulis ir kylantys konfliktai bus daug lengviau valdomi.

Kitaip nei Fukuyma, kuris teigè, kad pagrindiniai JAV nacionaliniai interesai XX a. pabaigoje virto visų pripažįstamomis universaliomis vertybėmis, Huntingtonas tvirtino, kad ir ateityje konfliktai neišnyks. Tik jie kils jau ne tarp skirtingomis ideologijomis besiremiančiu valstybių, bet tarp skirtingomis religijomis besiremiančiuc civilizacijų. Skirtingos religijos skaido žmoniją ir puoselëja skirtingas vertybes. Čia, kaip matome, Huntingtonas, kitaip negu Fukuyama, kuris akcentavo pasaulio globalumą ir vieningumą, siūlo pirmiausia kreipti dèmesį į išliekančią pasaulio fragmentaciją. Juk beveik kiekvienoje iš civilizaciju yra didžiosios valstybės, kurios prižiūri gretimas valstybes, ir tokiu būdu civilizacija sutelkia pakankamai galios, kad galètų dalyvauti, valdant pasauli, tarptautinëje galių balanso sistemoje. Kiekvienos civilizacijos didžiosios valstybės ne tik prižiūri savo regionus, bet ir, įsitraukdamos į aljansus, derėdamosios tarpusavyje ar užimdamos tam tikras pozicijas drauge valdo ir tarptautinius konfliktus. Pagrindinès valstybės, panašiai kaip Hanso Morgenthau ${ }^{3}$ darbuose aprašyta tarptautinè sistema, elgsis dvejopai, priklausomai nuo to, kokiame iš dvieju galimų regionu jos bus atsidūrusios. Tos, kurios atsidurs civilizacijos regione be aiškios dominuojančios valstybès, įsitrauks į vidinius civilizacijos nesutarimus ir sieks išsikovoti pagrindines valstybės pozicijas. $\mathrm{O}$ tos, kurios atsidurs greta sunkiai nustatomų civilizacijų ribų dèl savo neapibrèžtos padèties naujoje tarptautinëje sistemoje, įsitrauks į konfliktus tarp civilizacijų.

Kadangi Huntingtono realistinis požiūris sukèlè daugiau ginčų nei sutarimo, JAV užsienio politikos formuotojams Fukuyamos idealistiniai argumentai pasirodè patrauklesni. Buvo patikèta, kad JAV nacionaliniai interesai iš esmės yra globalūs žmonijos interesai, o pačios Jungtinės Valstijos, žlugus Sovietu

\footnotetext{
${ }^{2}$ Fukuyama F., „The End of History?", National Interest 16, 1989, p. 3-18; Huntington S. P., The Clash of Civilizations and the Remaking of World Order, Simon \& Schuster, 1996.

${ }^{3}$ Morgenthau H. J., Power among Nations: The Struggle for Power and Peace, 1985.
} 
Sajungai, tampa pasaulio hegemonu. Bet, jeigu jau atëjo "Amerikos laikas“, tai ką tuomet reikètų daryti? Deja, atsakymo ị šį klausimą Fukuyama taip ir nepasiūlè. Ką daryti su šia nauja atsivèrusia tarptautinės sistemos valdymo galimybe, liko neaišku.

Susidariusį idèjinį vakuumą padëjo užpildyti paskutiniajame XX a. dešimtmetyje įsisiūbavęs ekonominės globalizacijos procesas. Nors negalima nurodyti konkrečios datos ar įvykio, kokiu šaltojo karo metais tapo Kennano tekstas apie sovietų sulaikymo būtinybę, bet būtent globalizacija kaip tarptautinės sistemos valdymo koncepcija užvaldė JAV užsienio politikos elito sąmonę.

Globalizacija buvo patraukli tuo, kad šiuo atveju atrodo, jog procesai, kuriu metu valstybès igyvendina liberalios rinkos ir demokratinio valdymo principus, yra ir pagrịsti racionaliais kiekvienos iš valstybių interesais. Todèl tie procesai vystosi tarsi savaime, „,autopiloto" principu. Tarptautinès sistemos valdymo funkcijas galima susiaurinti iki proceso priežiūros ir skatinimo, o karinès jëgos naudojimas tampa beveik nereikalingas.

Pagrindinis globalizacijos sistemos argumentas buvo tas, kad visos šalys nori ekonominès gerovès. $\mathrm{O}$ vienintelis būdas tai pasiekti yra savo rinku atvėrimas globaliai konkurencijai. Vietinės rinkos atvėrimas konkurencijai ir globalaus investicinio kapitalo pritraukimas neimanomas be skaidrumo užtikrinimo, korupcijos ir biurokratinio kišimosi į rinkos veikimą išgyvendinimo ir investuotojų apsaugos užtikinimo. Pagal savo prigimtį šios reformos oponuoja ir autoritariniam valdymui. Pagaliau valstybių sienų atidarymas užsienio kapitalo investicijoms neišvengiamai skatins žmogaus teisiu pripažinimą ir demokratijos issigalëjimą. Per gana trumpą laikotarpi visos šios idejjos paveiks socialinę sistemą, paskatins politinius pasikeitimus. Režimai turès pasiduoti demokratinėms permainoms, jeigu nenorés prarasti jau pasiektos ekonominės pažangos.

Huntingtonas teigè, kad nevakarietiškų civilizacijų kultūrinės normos leis valstybėms atverti savo rinką užsienio investicijoms, kartu atmetant vakarietiškas vertybes, šis jo argumentas neįikino JAV užsienio politikos formuotoju, kuriems globalizacijos idealizmas atrodė patrauklesnis. Tai buvo ryšku Billo Clintono Nacionalinio saugumo strategijoje, kuri ne tik buvo dešimt kartu ilgesnè nei minètas Busho vyresniojo pasirašytas dokumentas, bet turëjo taiklu pavadinimą "Isipareigojimas ir plètra“ (ang. Engagement and Enlargement). Clintono nacionalinio saugumo strategija ne tik ragino JAV likti ịsipareigojusia, bet ir aktyviai veikti, skatinant tarptautinę prekybą ir demokratinių vertybių plètrą.

Globalizacijos sistemos poveikis buvo aiškus tada, kaip Clintono administracija rinkosi užsienio politikos kryptį. Administracija siekẻ bendradarbiauti su Kinija ir skatinti ekonominius, socialinius ir politinius pokyčius šioje šalyje. Vidurio ir Rytų Europoje administracija rèmè greitą privatizaciją ir perëjimą prie rinkos ekonomikos teigdama, kad tai leis atsirasti viduriniajai klasei, kuri ir sukurs socialines sąlygas demokratijai įsivyrauti. Šis požiūris, kuris dar žinomas kaip Vašingtono konsensusas, pasirode priimtinas Tarptautiniam valiutos fondui sudarant Lotynų Amerikos ar krizę išgyvenusios Azijos finansu restruktūrizavimo programas.

Didejjantis pasitikëjimas demokratinės taikos hipoteze, skatino pastangas 
rūpintis demokratinių vertybių eksportu. Kaip pažymëjo Kissingeris, prielaida, kad demokratinès valstybės nekariauja viena prieš kitą, buvo Amerikos idealizmo pagrindinis elementas, lemiantis JAV užsienio politiką nuo mažiausiai Woodrowo Wilsono laiku $u^{4}$. Smallui ir Singeriui, kurie savo straipsnyje pabandè sukritikuoti šį svarbiausią Amerikos įsitikinimą ${ }^{5}$, nepasisekè, nes tai kèlè dar didesnį dėmesį. Demokratinès taikos tyrinëjimai per XX a. paskutinijį dešimtmetį ir XXI a. pradžioje tapę viena iš labiausiai išplèstų tyrimų krypčių rẻmė konvencija tapusią idejją, kad taiką galima užtikrinti skleidžiant amerikietiškąsias vertybes, demokratijos principus ir iš emės liberalizuojant nacionalines ekonomikas.

\section{Neokonservatoriškas guodimasis}

Taigi globalizacija dominavo XX a. paskutiniame dešimtmetyje JAV užsienio politikoje, o jos intelektualūs oponentai buvo marginalizuoti. Nors Huntingtono "Civilizacijų susidūrimą"skaitė ir ji aptarinėjo, teksto poveikis buvo menkas. Kitų autorių darbai tiesiog buvo ignoruojami. Taip nutiko ir tiems, kurie XX a. paskutiniame dešimtmetyje suformulavo ideologiją, kuri vèliau ir tapo neokonservatizmu.

Ši ganėtinai nedidelè intelektualų grupè pritarè pagrindinei globalizacijos sistemos tezei, kad po Sovietų Sąjungos žlugimo JAV vertybés plačiai pasklido ir yra priimamos visoje tarptautineje sistemoje. Tačiau, pasak ju, to nepakanka. Tam, kad būtų užtikrinta proceso tąsa, reikalingi aktyvūs JAV veiksmai, numatant pasekmes. Ju manymu, JAV tik pasyviai stebi įvykius ir nnesistengia kurti kažką naujo ${ }^{6}$. Be plano arba strategijos nebuvo pasinaudota galimybe sukurti JAV nacionalinius interesus vertinančią ir palaikančią tarptautinę tvarką ${ }^{7}$. Be kita ko, silpna Amerikos lyderystè netgi skatino daugeli sajungininku prieiti prie išvados, kad JAV negalima pasitikèti. Tai skatino ieškoti alternatyvų JAV lyderystei tarptautiniuose reikaluose - atsirado nauja tendencija, kuri neigia šalies gebẻjimą kurti ir daryti įtaką tarptautinei sistemai, atsižvelgiant į savo vertybes ir interesus ${ }^{8}$.

Neokonservatoriams ypač rūpëjo valstybės - atskalūnès, kurios galëjo

\footnotetext{
${ }^{4}$ Kissinger H., Diplomacy, New York: Simon \& Schuster, 1994.

${ }^{5}$ Small M., Singer J. D., „The War Proneness of Democratic Regimes, 1816-1965“, Jerusalem Journal of International Relations 1, 1976, p. 50-69.

${ }^{6}$ Ceaser J.W., "The Great Divide: American Internationalism and Its Opponents" in Kagan R., Kristol W., eds., Present Dangers: Crisis and Opportunities in American Foreign and Defense Policy, Encounter Books, 2000, p. 25-43.

7 Kristol W., Kagan R., „Introduction: National Interest and Global Responsibility“ in Kagan R., Kristol W., eds., Present Dangers: Crisis and Opportunities in American Foreign and Defense Policy, Encounter Books, 2000, p. 3-24.

${ }^{8}$ Gedmin J., Kagan R., Kristol W., eds., Present Dangers: Crisis and Opportunities in American Foreign and Defense Policy, Encounter Books, 2000, p. 179-196.
} 
kenkti tarptautinei tvarkai. Tokiomis diktatūromis laikomos Sandamo Husseino Irakas ir Śiaurès Korèja. Neokonservatoriai manė, kad būtina imtis vykdyti „režimų kaitos“ politikos, kuri ne tik atgrasintų priešišką šių valstybių elgesį, bet ir neleistų taip elgtis tokioms kylančioms valstybėms kaip Kinija”.

Kitaip nei kitų teorijų šalininkai, neokonservatoriai nepasisakè prieš globalizaciją (žr., pvz., Paulo Wolfowitzo argumentus dèl prekybos su Kinija skatinimo ${ }^{10}$ ). Jie pritarè su atvira rinka siejamomis idëjoms ir netgi teigè, kad didejanti tarptautinè prekyba ir investicijų srautai skatina politinio liberalizavimo bei demokratizacijos procesus. Bet kaip ir Huntingtonas, neokonservatoriai klausè, ar globalizacija neišvengiamai skatina procesą tinkama linkme. Ekonominè gerovè gali būti nepakankama prielaida, užtikrinant tarptautinę tvarką. Diktatūroms tai gali būti nepakankamas veiksnys, atgrasantis jas nuo netinkamo elgesio. Tais atvejais, kai juc elgesys gali grasinti JAV nacionaliniams interesams arba tarptautiniam įsipareigojimui skatinti su laisva rinka pagrịstą demokratiją, JAV turi būti pasiruošusios panaudoti jègą, jei to prireiks, netgi be neišvengiamų kaltinimų dèl tokių veiksmų stiprumo ir arogancijos. Jei tai nebus padaryta, valstybės - atskalūnès, kurių tikslas ne tik išstumti JAV iš hegemono pozicijų, bet ir apskritai sužlugdyti su laisva rinka grįstą demokratiją, mes iššūki ir galiausiai sužlugdys tarptautinę sistemą.

Taigi būtina, kad JAV aktyviai gintų tarptautinę sistemą, kurioje ji dominuoja. Šią nuostatą neokonservatoriai gynè visiškai atvirai - pasaulis, kuriame Amerika dominuoja yra teisingas pasaulis o Amerikos vertybių dominavimas ir yra pagrindinis JAV nacionalinis interesas ${ }^{11}$.

Neokonservatoriai suprato, kad jie nutolo nuo tradicinio amerikietiško konservatorių požiūrio į JAV vaidmenį tarptautinëje sistemoje. Tradiciniai konservatoriai buvo arba izoliacionistiniu, arba realistinių pažiūrų ${ }^{12}$. Pastarosios atsirado anksčiau ir žmonės tikrai galvojo, kad JAV yra išskirtinè ${ }^{13}$. Manydamas, kad tarptautinè sistema bus amžinai priešiška Amerikos demokratijai, palikdamas postą George'as Washingtonas patarè savo tautiečiams vengti įsitraukti i užsienio šaliu reikalus. Nors Woodrowas Wilsonas ir nesugebëjo atsikratyti šio įpareigojimo bei neleisti šaliai likti būti izoliuotai tarpukario laikotarpiu, po Antrojo pasaulinio karo pabaigos JAV vis tiek tapo globalia galybe. O šaltojo karo metu neliko kitos išeities tik arba atsitraukti, arba pradèti kovą su Sovietų Sajunga dèl dominavimo. Konservatoriai tuo metu laikési realistinès pozicijos, kad JAV interesus galima apsaugoti, nesiveliant į moralinius ar etinius svarstymus.

Antra vertus, nuo Woodrow Wilsono laikų Amerikos politinè kairè

\footnotetext{
${ }_{9}$ Kristol, Kagan (6 nuoroda).

${ }^{10}$ Wolfowitz P., "Statesmanship in the New Century" in Kagan R., Kristol W., eds., Present Dangers: Crisis and Opportunities in American Foreign and Defense Policy, Encounter Books, 2000, p. 324-332.

${ }^{11}$ Kristol, Kagan, (7 nuoroda), p. 24.

${ }^{12}$ Ceaser, (6 nuoroda).

${ }^{13}$ Gaddis J. L., Surprise, Security and the American Experience, Harvard University Press, 2004.
} 
pasisakẻ už įsitraukimą ị tarptautinius reikalus taip skleidžiant ir stiprinant JAV vertybes. Liberalios pozicijos šalininkų mintys dèl aktyvios JAV užsienio politikos dominavo politikos tyrimų institucijose tarpukariu, idealistinę sistemą pavertė kone dèstoma disciplina. Dėmesys vertybėms priartino neokonservatorius prie idealistinès, o ne prie konservatoriškos pozicijos ${ }^{14}$. Daugelis ju kritikavo Nixono administraciją, kuri paaukojo Amerikos įsitikinimą tam, kad į savo pusę būtų patraukta Kinija. Panašiai Clintonas buvo kritikuojamas ir dẻl to, kad 1993 m. parèmė Jelcino manevrus prieš demokratiškai išrinktą įstatymų leidžiamają valdžią ${ }^{15}$. Šis fundamentalus nutolimas nuo konservatoriškų ideju labiau idealistinės užsienio politikos link pelnẻ ideologijai „neo“ priešdèlį.

\section{Neokonservatorių laikas}

Neokonservatorių argumentai nebuvo išgirsti, ir tai tikrai lemė ne faktas, kad jie ragino JAV užsienio politiką susieti su šalies vertybẻmis ${ }^{16}$, iš tikrujų tokia mintis netgi kilo tiems, kurie labiausiai žavėjosi Amerikos užsienio politikais. Tiksliau sakant, tuomet, kai akivaizdžios grẻsmės nebuvo, mintis, kad galima JAV nacionalinių interesu siekti ir naudojant jẻgą, kẻlè susirūpinimą. Karinès jẻgos panaudojimas buvo vertinamas kaip nereikalingos išlaidos, jei tikslų galima buvo pasiekti kitomis priemonėmis, pavyzdžiui, kaip teigè globalizacijos teorijos šalininkai, paprasčiausiai remiantis globalios rinkos jẻgų logika. Nebuvo jokios priežasties naudoti jẻgą tol, kol tarptautinė sistema buvo daugmaž stabili, o ji tokia ir buvo iki 2001 metų rugsẻjo 11 d. įvykių.

İtaka, kurią rugsėjo 11-oji padarè JAV užsienio politikų įsitikinimams dèl tarptautinès sistemos stabilumo, buvo milžiniška. Iš tikruju, "Al-Qaeda" taikẻ modernų karą nekonvencinėmis priemonėmis. Vietnamo karas žymėjo pabaigą karybos istorijoje. Nuo pat Prancūzijos revoliucijos kariuomenès buvo įtrauktos į vadinamajii „,sekinamąji “ karą arba ilgai trunkantį karą sekinti priešą. Masinio naikinimo ginklų, nuo šautuvų iki kulkosvaidžiais, tankų ir karinės aviacijos, atsiradimas nulėmè tai, kad per karą gali žūti tiek daug žmonių. Viena iš Vietnamo karo pamoku yra tai, kad „sekinamojo“ karo aukos reiškia pralaimẻjimą ir tai pusei, kuri patiria mažiau netekčių. Po karo Vietname JAV kariuomenè sukūrè visiškai naują karo koncepciją. Nauja doktrina, taktika, irranga ir mokymo sistema buvo sutelkta ne iz ",sekinamąjı" karą, bet karas turès būti laimėtas, atakuojant strateginius priešo taškus (tokius, kurie igalina priešą

\footnotetext{
${ }^{14}$ Bennett W. J., „Morality, Character and American Foreign Policy“ in Kagan R., Kristol W., eds., Present Dangers: Crisis and Opportunities in American Foreign and Defense Policy, Encounter Books, 2000, p. 289-306.

${ }^{15}$ Rodman P. W., , Russia: The Challenge of a Failing Power" in Kagan R., Kristol W., eds., Present Dangers: Crisis and Opportunities in American Foreign and Defense Policy, Encounter Books, 2000, p. 75-98.

${ }^{16}$ Bennett, (14 nuoroda).
} 
kovoti toliau, net ir su vadovavimu ir kontrole bei materialine baze).

Rugsëjo 11-osios atakų rengèjai nusitaikè ic pati JAV galios centrą, jos ekonomikos pamatą Niujorke. Poveiki gerai iliustruoja faktas, kad po ataku buvo uždaryta Niujorko vertybiniu popierių birža. Nutiko dar daugiau, nes atakų sukeltas šokas paskatino rimtą dekapitalizaciją (Dowo Jones'o indeksas iki rugsẻjo $11 \mathrm{~d}$. buvusį lygi pasiekè tik po kelerių metų) ir pasaulinę recesiją. Globalizacijos kaip JAV užsienio politikos žlugimas buvo viena iš su rugsejjo 11-osios įvykiais siejamų netekčių. Ji negalejjo paaiškinti tarptautinei sistemai suduoto smūgio ir nepasiūlè jokių atsako gairių.

Situacija, i k kurią pateko JAV po teroristų atakų rugsëjo 11-osios, reikalavo naujos užsienio politikos, ir neokonservatoriams pasitaikè puiki proga pasiūlyti savo paslaugas. Keletas neokonservatorių užėmė svarbius postus Busho administracijoje, ir ši aplinkybė taip paveikè, kad buvo priimtas sprendimas, formuojant užsienio politiką, remtis neokonservatoriškaja vizija. Antra vertus, nereikètu ignoruoti ir nepripažinti savotiško intelektualinio sistemos patrauklumo. Krizès akivaizdoje, kai reikejjo atsakyti į klausimą, ką daryti, ji labai tiko.

Neokonservatizmo patrauklumą didino ir tai, kad globalizacija buvo ši nauja teorija. Ji tik papilde pastarają mintimi, jog valstybių - atskalūnių - diktatoriai siekia destabilizuoti tarptautinę sistemą, ir kad į tai nebegalima nekreipti dèmesio. Neokonservatyviosios sistemos perèmimas buvo nesudètingas, nes teorija nesiūlè radikalaus požiūrio į daugeli problemų ir valstybių pasikeitimo. Vienintelis pasikeitimas buvo susijęs su būtinybe pradèti taikyti „režimų kaitos“ politiką nesutinkančių laikytis tarptautinių normų valstybių - atskalūnių atžvilgiu. Ten, kur tokių valstybių keliama grèsmė yra pakankamai didelè ir kur neveikia diplomatinès ir ekonominès priemonės, buvo planuojama panaudoti ir karinę jègą.

Neokonservatoriškoji doktrina, kaip ir daugelis kitų tarptautinių santykių teoriju (pvz., idealizmas, realizmas ir globalizacija) šalininkai, mano, kad pagrindiniai tarptautinès sistemos veikejjai yra valstybes, o visi kiti veikia per valstybes. Taigi skubus atsakas tarptautinei teroristinei organizacijai „Al-Qaeda“ buvo nukreiptas į teritoriją valstybės, kurioje ji rezidavo, pirma, Afganistaną. Vèliau JAV įsitraukè į kompleksinę finansinę, ekonominę, diplomatinę, slaptą žvalgybos ir karinę operacija, norėdama sunaikinti „Al-Qaeda“ ir kitose pasaulio šalyse.

Neokonservatizmas buvo įteisintas 2002 m. rugsejjo 17 d. prezidento Busho pasirašytoje Nacionalinio saugumo strategijoje. Dokumento preambulëje išdėstyti svarbiausi sistemos argumentai. Teigiama, kad JAV turi be precedento karinę, politinę ir ekonominę galią tarptautinėje sistemoje. JAV vengs naudoti šias galias, siekiant vienašališkos naudos, bet naudos ją, kad remtų laisva rinka grindžiamą demokratiją, skleistų universalią žmogiškają vertybę - laisvę visiems pasaulio piliečiams. JAV su mažiau išsivysčiusiomis valstybėmis sieks įveikti skurdą, nes skurde klesti diktatūros ir teroristinès organizacijos bei trukdo įsigalèti laisvei ir gerovei.

Pagrindiniame strategijos tekste toliau dėstomos šios mintys. Iૃvadiniame skyriuje "Amerikos tarptautinės strategijos apžvalga" pristatoma neokonservatorių straipsniuose plèsta vizija, kad JAV gali padaryti pasauli geresniu. 
Skyriaus pradžioje akcentuojama, kad po šaltojo karo JAV tapo galingiausia pasaulio valstybe, todèl, pasinaudodama savo pozicija, ji ịsipareigoja veikti pasaulio tvarką: užtikrinti klestėjimą per laisvajją rinką, laisvę per demokratiją. Antrame skyriuje, kuris paremtas Prezidento Busho 2002 m. birželio 1 d. JAV Karo akademijoje (Vest Pointas, Niujorkas) pasakyta kalba ${ }^{17}$, kurioje vienareikšmiškai pripažistama, kad šios nuostatos bus laikomos universaliomis vertybėmis ir tikslais. Keletas kitų dokumento skyriu gali būti siejami tiek su globalizacija, tiek ir su neokonservatorių idejjomis. Tai ypač pasakytina apie šeštaji ir septintaji skyrius, kuriuose minima auganti tarptautinè prekyba ir gerovè bei demokratijos sklaida. $2002 \mathrm{~m}$. Nacionalinio saugumo strategija išsiskyrè tuo, kad joje daug dėmesio susilaukè valstybès - atskalūnès. Ypač tos, kurios turi noro pasigaminti ir panaudoti masinio naikinimo ginklą. Penktasis skyrius „Sukliudyti priešams grasinti mums, mūsų sajungininkams ir mūsų draugams masinio naikinimo ginklais" šiuo požiūriu buvo išskirtinis. Skyriuje pažymima, kad tokios šalys ne tik nepripažįsta laisvès ir taikos, bet net remia teroristines organizacijas. Šių valstybiu gebejimas panaudoti šiuolaikines technologijas suteikia joms galimybę sukurti ginklus, kuriais jos gali grasinti tarptautinei sistemai ir jos vertybėms. Tad Jungtinès Valstijos nebegali vien reaguoti į valstybių - atskalūnių - akibrokštus, jos turi būti pasiruošusios imtis aktyvių veiksmų ir prevencinių priemonių ten ir tada, kur bus reikalinga.

Susirūpinimas, kuris buvo išsakytas dokumente dẻl valstybiu atskalūniu - ir ju galimybės kelti grèsmę regioniniam ir tarptautiniam saugumui, atspindejjo garsių neokonservatorių XX a. paskutiniojo dešimtmečio darbuose išsakytas idejjas. Vienas iš pagrindiniu jų taikinių buvo Irakas. Buvo pripažįstama, kad prezidentas Bushas vyresnysis ",politiškai bankrutavo“, nes savo laiku nesugebëjo pašalinti Sadamo Huseino iš valdžios. Neokonservatoriai neklausè tu, kurie sakè, kad Sadamo režimas yra labai svarbi galios Artimuosiuose Rytuose sudėtinė dalis ${ }^{18}$. Ju manymu tikimybė, kad Huseinas pagamins masinio naikinimo ginklą, yra didžiausia grèsmè regioniniam ir tarptautiniam stabilumui ${ }^{19}$. Ir todèl jis turi būti pašalintas iš valdžios.

\footnotetext{
${ }_{17}$ Ši kalba buvo pirmasis pripažinimas, kad administracija užsienio politikoje remsis neokonservatoriškajaja sistema.

${ }^{18}$ Perle R. N., „Iraq: Saddam Unbound“ in Kagan R., Kristol W., eds., Present Dangers: Crisis and Opportunities in American Foreign and Defense Policy, Encounter Books, 2000, p. 99-110.

${ }^{19}$ Abrams E., „Israel and the „Peace Process“ in Kagan R., Kristol W., eds., Present Dangers: Crisis and Opportunities in American Foreign and Defense Policy, Encounter Books, 2000, p. 221-240; taip pat Perle, (note 17).
} 


\section{Neokonservatizmo liūnas}

Dabar, pažvelgus atgal, akivaizdu, kad sprendimas įsiveržti ị Iraką, siekiant pakeisti režimą šioje Artimujų Rytų šalyje, buvo skaudžiausias smūgis JAV užsienio politikoje dominavusiai neokonservatorių doktrinai. Iš tikrujų tai, kad nebuvo surastos masinio naikinimo ginklu slaptavietės, buvo nesugebẻta užtikrinti taikos po Sadamo Huseino nuvertimo, užkirsti kelio staigiam Teherano įtakos ir galios plitimui Persijos įlankos regione, JAV pasitraukimo atveju, sąlygojo neokonservatoriškujų idejjų atmetimą net pačių aistringų vakarykščiu šalininkų tarpe.

Daug kas pastebi, kad neokonservatoriu ideju pabaigą labiausiai lemia dabartinis ad hoc karo Irake pobūdis. Sprendimas įsiveržti i Iraką buvo paremtas dviem argumentais. Pirma, Sadamo Huseino branduolinio, biologinio ir cheminio ginklo programa, kartu su deklaruotu pasiryžimu kovoti nekonvencinį karą, leido daryti prielaidą, kad asimetriški JAV ir Irako santykiai gali pastūmèti pastarajị perduoti masinio naikinimo ginklus ị jo valią vykdančiu tarptautinių teroristų rankas. Antra, Sadamo Huseino diktatoriškas režimas buvo visiška priešingybė gerovei ir demokratinėms normoms, kurios sudarẻ JAV vyraujančią tarptautinę sistemą. Tačiau tuomet, kai išsiaiškinta, kad Irako masinio naikinimo ginklu programa nebuvo tokia grėsminga, kaip manyta, pirmasis argumentas prarado savo reikšmę. O antrasis argumentas ir patiems neokonservatoriams niekada nebuvo pakankama prielaida pateisinti karinės jẻgos naudojimą režimo kaitai užtikrinti. Tiesą pasakius, jie argumentavo, kad kariné jẻga galètų būti panaudota tik tada, jei kiltu grèsmé tarptautinei tvarkai. Kitais atvejais diktatūrą reikia nuversti ir panaudoti ekonomines sankcijas bei laisvès, gerovės "demonstracijąa" kaimyninèse šalyse. Taigi, gerokai sumenkus pirmajam argumentui, neokonservatoriu požiūriu, beveik nebeliko invazijos į Iraką pateisinimo, jei spręstume iš administracijos pateiktos situacijos.

Tačiau iš tikruju ne visai taip. Galimas ir kitoks logiškas karo Irake pateisinimas. Tiek neokonservatoriai, tiek ir globalizacijos šalininkai sutinka, kad diktatoriai atriboja savo valstybes nuo tarptautinės prekybos ir investiciju, ir taip darydami jie pasmerkia jas skurdui. Globalizacijos sistemos šalininkai teigia, kad visuomenès nepasitenkinimas arba pripažinimas, kad jos ekonominiai interesai yra pažeisti, galiausiai priverčia diktatorius atidaryti sienas, o neokonservatoriai mano, kad kai kurias atvejais diktatoriai gali pabandyti pasipriešinti ir mesti iššūkị visai tarptautinei sistemai. Busho administracija pasiremė kaip tik antraja šio argumento dalimi ir padarẻ tiesmukišką išvadą, kad rugsëjo 11-osios atakos aiškiai rodo, ko diktatoriai gali pasiekti, išnaudodami terorizmą. Masinio naikinimo ginklai didina jų keliamą grėsmę. O kadangi Irakas turëjo tokiu ginklu plètojimo programą, tai Sadamas Huseinas turëjo būti pašalintas iš valdžios.

Prezidento administracija ir jos patarëjai neokonservatoriai taip pat turëjo atkreipti dėmesị i egzistuojantị mechanizmą, kurio dẻka diktatoriai vis tiek išlie- 
ka valdžioje, net jei visuomenẻ išreiškia nepasitikẻjimą jais. Jei jiems nepavyksta pakreipti šio nepasitenkinimo jiems palankia kryptimi, tuomet globalizacijos argumentai yra įtikinami. Diktatūros turi būti susitvardančios, tačiau jos vis dèlto griūva. Tokią Sovietų Sajungos baigti prognozavo ir Kennanas. Tačiau, kaip pabrèžia neokonservatoriai, Irako „sulaikymas“ ekonomine sankcija ir neskraidymo zona lemė tai, kad šalis pradëjo viso Viduriniujų Rytų regiono destabilizavimo procesą ${ }^{20}$. Tai prisidejjo prie besitęsiančio Izraelio ir Palestinos konflikto, kuriuo Saddamas Husseinas buvo asmeniškai suinteresuotas. Tol, kol konfliktas ruseno, jis galejo vaizduoti Jungtines Valstijas kaip pagrindini žydų valstybės rèmëją, o save kaip arabų pasaulio atstovą, turintį tikslą ištrinti Izraeli iš politinio žemèlapio.

Iš tikruju galima teigti, kad kitos Viduriniujų Rytų regiono diktatūros savo visuomenės nepasitenkinimą režimu nukreipia Izraelio kryptimi. Išnaudodamos savo ekonominę ir politinę įtaką Palestinos atžvilgiu, jos iš esmès vetuoja bet kokį taikos susitarimą tam, kad Izraelio ir Palestinos konfliktas tęstųsi ir toliau, nes taip užsitikrinamas šaltinis, į kuri galima nukreipti visuomenės nepasitenkinimą. Režimo pasikeitimas Irake ne tik pašalintų žaidèją iš Izraelio ir Palestinos konflikto, bet tai būtų ir aiški žinia kitoms diktatūroms Irane, Sirijoje ir Saudo Arabijoje. Iš esmès karas Irake buvo reikalingas žingsnis, norint pasiekti, kad Izraelio ir Palestinos problema nebūtų antiliberalių režimų pateisinimo priemone. Kitos regiono šalys, taip pat ir Iranas, yra labiau integruotos į tarptautinės prekybos sistemą. Taigi jos turètų mažiau alternatyvų ir privalètų rinktis: arba įsitraukti į ekonomines ir politines reformas, arba patirti vidinį nestabilumą.

Šie labiau išplèsti argumentai ir strategija, kurios jie reikalauja, yra nepalyginamai labiau sudėtingesni nei ta, kurią po rugsejo 11-osios įvykiu suformavo Busho administracija, kuri atvedè i karą Irake. Argumentų ir strategijos pritaikymas bei realistinis laiko ir resursų įvertinimas galejo lemti sprendimą nepulti Irako. Tai galejo lemti, kad būtų buvusios apgalvotos karo pasekmès bent jau potencialaus konflikto su Iranu ir sunkumų su Sirija bei Saudo Arabija. Jei i tai būtų buvę atsižvelgta, strategijos logika ir kaštai būtų buvę aiškesni. Be to, faktas, kad nebuvo rasta masinio naikinimo ginklų, būtų buvęs nesvarbus.

Dèl įvairių priežasčių Busho administracija nesvarstė arba nepasirinko šios labiau integruotos ilgalaikès strategijos, kuri būtų atnešusi taiką i Artimuju Rytų regioną ir sužlugdžiusi paramą teroristams regione. Karo Irake pasekmès smogè Busho administracijos užsienio politikai, o tai lėmè, kad neokonservatizmo idejos JAV užsienio politikos elito atstovų buvo atmestos. Be to, kad neokonservatizmas buvo atmestas kaip nepavykusi strategija, išlieka problema, kad šiuo metu nèra kitos alternatyvos šiai krypčiai. Taigi neokonservatizmo atmetimas paremtas tuo, kad jis nepasiteisino konkrečioje situacijoje, bet ne tuo, kad, lyginant su kitomis teorijomis, jis yra nepalyginamai prastesnis. Tikėtina, kad tai sukels nemažai problemų JAV užsienio politikoje.

${ }^{20}$ Perle, (18 nuoroda). 


\section{Išvados}

Nors atsirado daugybė neokonservatizmo kritiku, tačiau jokia alternatyva iki šiol nebuvo pasiūlyta. Buvęs Prezidento Jimmy'io Carterio patarëjas nacionalinio saugumo klausimais Zbigniewas Brzezinsky's ragino atsigręžti i globalizacijos paradigmą kaip JAV užsienio politiką formuojančią teoriją ${ }^{21}$. Jis teige, kad bet kuris hegemonas sulauks pasipriešinimo vien todèl, kad jis yra hegemonas, todèl Brzezinsky's tvirtina, jog JAV bus tiesiog priverstos susitaikyti su tam tikru tarptautiniu nestabilumu. Jo požiūriu, Irakas, valdant Sadamui Huseinui, buvo toleruotino lygio nestabilumo pavyzdys. Iš tikruju yra kitu regionu, kur nestabilumas jau yra nebetoleruotinas. Noredamos su tuo kovoti, Jungtinės Valstijos turi veikti kartu su savo sajungininkais, kurdamos ir plèsdamos bendrų interesų vienijamą bendruomenę.

Vis dèlto Brzezinsky's pripažįsta, kad Jungtinès Valstijos tam tikrais atvejais gali būti priverstos veikti vienašališkai ${ }^{22}$. Taigi jo kritika gali būti apibendrinta taip - karas Irake buvo klaida, nes šiuo atveju įvyko pernelyg didelis "grèsmès" sureikšminimas. Brzezinsky'io požiūriu, Busho administracija užuot siekusi maksimalaus saugumo turëjo susitaikyti su tam tikro nestabilumo lygmens galimybe. Bet, kaip matome, iš esmès Brzezinsky's taip ir nepasiūlo kokio nors naujo sprendimo.

Josephas S. Nye jaunesnysis buvo vienas iš atkakliausiu neokonservatizmo kritikų. Kaip ir Brzezinsky's, jis, projektuojant JAV užsienio politiką, pasisake už grižzimą prie globalizacijos paradigmos. Jo požiūriu, nẻ vienas iš diktatoriu negali kelti rimtos grėsmès tarptautinei sistemai. Tikroji grésmė yra tai, kad JAV galios arogantiškas naudojimas ir piktnaudžiavimas ja, privers kritiškai mąstančius pasaulio piliečius vienytis ir priešintis hegemonui. Vadinasi, JAV turi daugiau remtis „švelniaja“, o ne "griežtaja“" galia, t.y. savo idealų ir vertybiu patrauklumu, o ne kariuomenès galia. Tik „,švelnioji“ galia sumenkins diktatorių pastangas kurstyti nesantaiką ir mesti iššūkị pasauliniam stabilumui. Jungtinės Valstijos gali žymiai padidinti savo „,̌̌velniająٌ galią skirdamos resursu siekti svarbiems interesams, ribodamos savo nacionalinius interesus ir siekdamos socialinio teisingumo bei ekonominès ir politinès tvarkos ${ }^{23}$.

Ir Brzezinsky's, ir Nye teigè, kad atsigręžimą i neokonservatizmą lẻmė emocijomis nuspalvintas manymas to, kad rugsèjo 11-osios teroristinès atakos destabilizavo tarptautinę sistemą. Iš tikruju visus neokonservatizmo kritikus vienija bendras fundamentalus įsitikinimas JAV ekonominè ir politinè galios garantuojamu tarptautinės sistemos stabilumu. Ju nuomone, tikroji grèsmė sistemos stabilumui yra perdèta JAV reakcija ị ivvykius, kuri lemia neprotingą jẻgos naudojimą. Iš tikruju, tai jie pasisako už pragmatiškesnę užsienio politiką,

\footnotetext{
${ }^{21}$ Brzezinski Z., The Choice: Global Domination or Global Leadership, Basic Books, 2004.

${ }^{22}$ Ten pat.

${ }^{23}$ Nye J. S., Jr., The Paradox of American Power: Why the World's only Superpower Can't Go It Alone, Oxford University Press, 2002.
} 
atribotą nuo neokonservatorių idealizmo, kuri žymi tuo, kad JAV hegemonija vertinama kaip galimybė modeliuoti pasauli, kad jis atspindètų JAV vertybes, įskaitant teisę ir laisvę. Brzezinsky's akcentuoja, kad pagrindinis tikslas yra gerai veikianti tarptautine sistema. Čia ir slypi pagrindinis neokonservatoriu ir jų kritikų požiūrių skirtumas. Pirmieji nori kuo apčiuopiamesnių politikos rezultatu, daugiau laivès ir demokratijos, o antrieji sutinka susitaikyti su menkesniais rezultatais, bet išsaugoti stabilesnę tarptautinę sistemą.

Kadangi prie neokonservatizmo patrauklumo daug prisidejo Amerikos idealizmas, turètų būti atkreiptas dèmesys į jo aiškumą ir paprastumą. Brzezinsky'io ir Nye argumentai yra ne tik mažiau idealistiniai, jie taip pat per sudètingi, kad galima būtų jais vadovautis. Šiuos teiginius galima iliustruoti Princetono nacionalinio saugumo projektu, kuris buvo kuriamas trejus metus, ir kurio tikslas buvo nustatyti JAV užsienio politiką turėsiančią formuluoti sistemą. Labiausiai žinomi šalies su užsienio politika susiję mokslininkai buvo paprašyti parašyti ic pono $X$, t. y. George'o Kennano, panašų straipsni, tačiau projekto paskutinejje atskaitoje pripažistama, kad nepavyko to padaryti ${ }^{24}$. Tiesą sakant, ataskaitoje tvirtinama, kad tai, jog tarptautine sistema yra kompleksiška, neleidžia JAV užsienio politikos grịsti vienu viską vienijančiu teoriniu požiūriu $^{25}$. JAV turi atkreipti dèmesị į daugialypę grẻsmę, jos turi būti pasiruošusios panaudoti ir "griežtąą", ir "švelniąją" galią, jos turi siekti savo interesų igyvendinimo kartu su sajungininkais, jos turi veikti, remdamosi savo vertybėmis, o ne baimėmis. Jos turi kreipti dėmesį ne tik į šalių išorinius santykius, bet ir vidinę dinamiką, ir jos turi prisitaikyti prie informacijos amžiaus. Kadangi yra sudètinga kritikuoti bent kurį iš šių teiginiu, tai yra tik teiginių sąrašas. Vis tiek nebuvo rastas požiūris, kuris vienytu, o tai neleido darbo grupei nuveikti ką nors daugiau.

Tikriausiai tai yra laikmečio problema. Jungtinių Valstijų užsienio politikai griežtai atmetė Busho užsienio politiką ir jos nekonservatoriškajji pagrindą. Bet jis ir toliau pripažįsta pagrindines globalizacijos sistemos idejjas - JAV kaip pasaulinį hegemoną ir laisvos rinkos bei demokratijos svarbą. Dabar ir bet kurios kitos JAV užsienio politikos gairès turès remtis šiomis prielaidomis. Lieka neaišku, kokios yra grèsmès sistemai, ir kaip su jomis turi būti kovojama? O kol atsakymo į ši klausimą nèra, Jungtinių Valstijų užsienio politika yra ad hoc, kai su kiekviena nauja krize ar problema yra veikiama atskirai, nesiejant vienų su kitomis. Dèl šios „neholistinès“ sampratos Jungtinès Valstijos bus priverstos tik reaguoti į pasaulio politikos problemas ir užleisti iniciatyvą tiems, kas aiškiau sugeba apibrèžti savo nacionalinius tikslus ir interesus. Tarp jų tikriausiai išsiskirs Kinija, Iranas ir vèl agresyvëjanti Rusija.

\footnotetext{
${ }^{24}$ Ikenberry G. J., Slaughter A. M., Forging a World of Liberty under Law: U. S. National Security in the $21^{\text {st }}$ Mentury, The Princeton Project Papers, The Woodrow Wilson School of Public and International Affairs, Princeton University, 2006, p. 4, 58.

${ }^{25}$ Ten pat, p. 13.
} 


\section{Literatūra}

1. Abrams E., „Israel and the „Peace Process“ in Kagan R., Kristol W., eds., Present Dangers: Crisis and Opportunities in American Foreign and Defense Policy, Encounter Books, 2000, p. 221-240.

2. Bennett W.J., "Morality, Character and American Foreign Policy“ in Kagan R., Kristol W., eds., Present Dangers: Crisis and Opportunities in American Foreign and Defense Policy, Encounter Books, 2000, p.. 289-306

3. Brzezinski Z., The Choice: Global Domination or Global Leadership. Basic Books, 2004

4. Ceaser J.W., „The Great Divide: American Internationalism and Its Opponents" in Kagan R., Kristol W., eds., Present Dangers: Crisis and Opportunities in American Foreign and Defense Policy, Encounter Books, 2000, p. 25-43.

5. Fukuyama F., „The End of History?“ National Interest , 1989, 16, 3-18.

6. Gaddis J.L., Surprise, Security „, and the American Experience. Harvard University Press, 2004.

7. Gedmin J., „Europe and NATO: Saving the Alliance“ in Kagan R., Kristol W., eds., Present Dangers: Crisis and Opportunities in American Foreign and Defense Policy, Encounter Books, 2000, p. 179-196.

8. Huntington S. P., The Clash of Civilizations and the Remaking of World Order. Simon \& Schuster, 1996

9. Ikenberry, G. J., Slaughter A-M. Forging a World of Liberty under Law: U.S. National Security in the $21^{\text {st }}$ Century, Princeton Project Papers, Woodrow Wilson School of Public and International Affairs, Princeton University, 2006.

10. Kissinger, H. Diplomacy. New York: Simon \& Schuster, 1994

11. Kristol W., Kagan R., „Introduction: National Interest and Global Responsibility" in Kagan R., Kristol W., eds., Present Dangers: Crisis and Opportunities in American Foreign and Defense Policy, Encounter Books, 2000, p. 3-24.

12. Morgenthau H.J. Power among Nations: The Struggle for Power and Peace, 1985

13. Nye J.S, Jr., The Paradox of American Power: Why the World's only Superpower Can't Go It Alone. Oxford University Press 2002.

14. Perle R.N., "Iraq: Saddam Unbound” in Kagan R., Kristol W., eds., Present Dangers: Crisis and Opportunities in American Foreign and Defense Policy, Encounter Books, 2000, p. 99-110.

15. Rodman P.W., "Russia: The Challenge of a Failing Power" in Kagan R., Kristol W., eds., Present Dangers: Crisis and Opportunities in American Foreign and Defense Policy, Encounter Books, 2000, p.75-98.

16. Small M., Singer J. D., „,The War Proneness of Democratic Regimes, 18161965“. Jerusalem Journal of International Relations 1976, 1, 50-69.

17. Wolfowitz P., "Statesmanship in the New Century“ in Kagan R., Kristol W., eds., Present Dangers: Crisis and Opportunities in American Foreign and Defense Policy, Encounter Books, 2000, p. 307-336.

18. X [George F. Kennan], „Sources of Soviet Conduct“, Foreign Affairs, July 1947. 